\title{
The optimal taxation of logistics industry in China
}

\author{
Dongmei Wang ${ }^{1}$, Cairong Zhou ${ }^{2}$, Hejie Sun ${ }^{1}$ \\ ${ }^{1}$ School of Economics and Management, Beijing Jiaotong University (China) \\ ${ }^{2}$ Chinese Academy of Tropical Agricultural Sciences (China) \\ dmw12345@263.net, zhoucairong0627@126.com,hjsun@bjtu.edu.cn
}

\section{Abstract:}

Purpose: Putting forward policy proposes to improve the tax policy of the logistics industry.

Design/methodology/approach: Based on Cobb-Douglas production function model, combined theoretical analysis, this paper puts forward Cobb-Douglas production function expansion model, and using the function estimates the optimal tax burden level of China's logistics industry.

Findings: The result of empirical analysis on the state-owned companies and the listed companies of transportation and storage industry show that, the actual tax burden of China's logistics industry is higher than the optimal taxation. This implies that tax problem has restricted the normal operation of the logistics industry in China.

Research limitations/implications: Affected by lack of Chinese logistics industry statistics, we only estimate the optimal taxation of state-owned logistics enterprises and listed companies of logistics. But, the two samples are the main force of the logistics industry in China, and the optimal tax calculation result is close, so we can believe that the calculation results are representative.

Originality/value: At present, the study of the tax burden on China's logistics industry is almost blank. This research estimates the optimal tax burden level of China's logistics industry, and puts forward recommendations to improve the tax policy of the logistics industry.

Keywords: logistics industry, optimal taxation, production function, China 


\section{Introduction}

The logistics industry in China is still in the early stage, is a new industry, but it links the social production and circulation, it has an important function on the smooth operation of social economy, it will become an accelerator to promote economic development. The logistics industry has a set of characteristics, such as low profit margins, low returns and long cycle on investment, this decides that it can't bear heavy tax burden.

The problem of tax burden is always the most acute, the most sensitive part that relates to the people's livelihood. Because it doesn't only constitute a state tax policy and the core content of the tax system, but also closely related with economic growth and social stability. Dongmei $y$ Songdong (2009), Dongmei y Cairong (2011) have analyzed tax burden of logistics industry in China, shows that the tax burden of logistics industry above the social average level. High level of tax burden has restricted the development of logistics industry; the existing tax system has been not adapted to the need of the logistics industry. The problems existing in the tax policy system of logistics industry become the bottleneck of influence the development, the tax system of the logistics needs to be optimized.

Study on the optimal taxation of logistics industry provides the theory basis for tax policymaking, it is extremely important to the improvement of the tax policy in logistics industry. January 1, 2012, business tax change VAT pilots in transportation industry and modern service industry in Shanghai. After the full implementation of the VAT reform in 2009, it is a symbolic event in the process of the tax system reform. Business tax change VAT is a major reform of promoting the economic structure adjustment and accelerating the transformation of the economic development, is also the important content of the structural tax cuts. How to use the opportunity of this reform, solve the tax problems that inhibit the development of logistics industry, it is an urgent need to study the issue.

\section{The research theory and methods}

The optimal taxation is determined by the maximum of gross domestic product. This paper uses Cobb-Douglas production function expansion mode as the foundation, which appeared in Barro (1990), analysis the relationship between gross domestic product, government spending and capital investment, and deduces the optimal taxation. We consider the economic production and utility function of household, enterprise and government department, and deduce the economy increasing function. 


\subsection{The relationship between tax burden and economic growth}

From the macroscopic, the tax is rooted in economic, only economic developed well, the tax will have plenty of sources. If other conditions remain unchanged situation, the economic growth will have a great influence on the tax. As in a slowing economic growth period, the proportion of taxable GDP will drop accordingly, tax growth will slow accordingly. If the tax grew more rapidly than economic, it may seriously weaken economic growth in the future.

About tax burden and economic growth, the more representative is the view of Supply school that the high tax has a negative impact on economic growth. This view comes from the analysis that tax has an impact on labor and capital: the high taxes for labor, real income of labor will drop, reducing the supply; At the same time improve labor costs, demand also reduce, causing the labor supply and demand gap, and to reduce the possibilities of the realization of the economic efficiency. Also, to capital demanders, higher taxes make investment cost increase and reduce capital needs; And to capital providers, high tax reduced capital gains, capital supply also reduced. Due to the high taxes that rising costs of production factors, yields down, and then to produce unfavorable effects on economic growth.

In China, as the Labor supply is rich, technological progress on economic growth contribution is low, so the economic growth is the main impetus for investment. We believe, the government's income scale and public spending level is low, public facilities and public service supply shortages, increases the marginal positive effect of public products provided by taxation, greater than the marginal cost of tax increases. Appropriate raising the proportion of taxes in GDP is good to expand investment and economic growth. As the tax amount has been bigger, tax increase again, because of the law of diminishing marginal returns, positive effect increases of tax provide public products will not make up marginal cost for the marginal tax , continue to improve the proportion of tax in GDP, go against stimulate social investment and economic growth. The net effect of tax depends on the relative size of these two forces. The tax and investment, economic growth is a nonlinear relation, investment, economic growth is the size of the tax concave function. As shown in Figure 1,

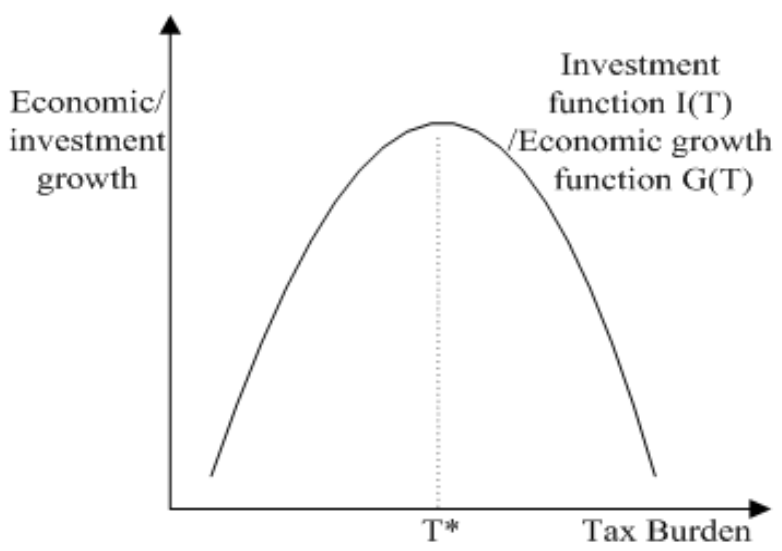

Figure 1. Economic (Investment) growth and Macro tax burden 


\subsection{Cobb-Douglas production function}

Cobb-Douglas production function is used to predict the countries and regions of industrial system or big enterprise's production and analysis of the development of production a means of economic mathematics model. It is the most widely used in economics a production function form, it in mathematical economics and economic metrology of research and application of important position. Cobb-Douglas production function is that

$$
Y=A(t) L^{\alpha} K^{\beta} \mu
$$

where $Y$ is industrial output, $A(t)$ is a comprehensive technical level, $L$ is the labor force in number, $\mathrm{K}$ is put into capital, generally refers to net value of fixed assets, and $\mathrm{a}$ is the elasticity coefficient of labor, $\beta$ is the capital of the output elasticity coefficient, $\mu$ said the influence of random disturbance, $\mu \leq 1$.

From this model, the main factors determining the level of development of industrial systems are the number of inputs of labor, fixed assets, and comprehensive technical level (including management level, the quality of the labor force, to introduce advanced technology, etc.) According to the combination of $a$ and $\beta$, it has three types:

- $a+\beta>1$, it is called an incremental reward type, showed that the technique used to expand the scale of production to increase output is favorable.

- $a+\beta<1$, it is called a diminishing reward type, showed that the technique used to expand the scale of production to increase output is pyrrhic.

- $a+\beta=1$, it is called a same reward type, showed that the production efficiency will not with the enlarging of the production scale and improve, only to improve the technical level, it will improve the economic benefits.

\subsection{Economic growth and the optimal taxation model}

Because of Cobb-Douglas production function is not suitable for use in the logistics industry, so I will find the right model. 


\subsubsection{The Household Department}

I begin with endogenous growth models that build on constant returns to a broad concept of capital. The household departments use Ramsey (1928) put forward an infinite-lived household in a closed economy utility function, as given by

$$
U=\int_{0}^{\infty} \frac{C^{1-\theta}-1}{1-\theta} e^{-p} d
$$

Household budget constraints,

$$
\Delta a=r \quad \# w-c
$$

where $\theta>0$, so that marginal utility has the constant elasticity $-\theta$. $c$ is consumption per person, $p>0$ is the constant rate of time preference, is the household real assets, $r$ is actual yields, $w$ is wage.

Every person works a given amount of time; that is, there is no labor-leisure choice. As is well known, the maximization of the representative household's overall utility in equation (2) implies that the growth rate of consumption at each point in time is given by

$$
\gamma=\frac{\Delta c}{c}=\frac{r-p}{\theta}
$$

The symbol $y$ denotes a per capita growth rate. I assume that the technology is sufficiently productive to ensure positive steady-state growth, but not so productive as to yield unbounded utility. 


\subsubsection{The Enterprise Department}

The Enterprise Sector use Cobb-Douglas function expansion mode:

$$
\begin{array}{ll}
Y=A G^{\alpha} L^{\alpha} K^{1-\alpha} & \text { (Enterprise production function) } \\
\text { Or } y=A g^{\alpha} K^{1-\alpha} & \text { (Per capita production function) }
\end{array}
$$

\subsubsection{The Government Department}

The Government departments carry out balance the budget, according to macro tax burden, tax is given by

$$
t=g=\tau^{*} \quad y \quad 0 \quad \tau \mathrm{r}=\frac{g}{y}
$$

Where $t$ is government revenue and $T$ is the tax rate. I have normalized the number of households to unity so that $g$ corresponds to aggregate expenditures and $t$ to aggregate revenues. Note that equation (6) constrains the government to run a balanced budget.

Substituting equation (5) into equation (6) yields

$$
g=(\tau A)^{\frac{1}{1-\alpha}} k
$$

\subsubsection{The determination of the optimal taxation}

Now, through the above three departments to push the basic formula, determined the optimal taxation.

The production function in equation (5) implies that the marginal product of capital is

$$
\frac{\partial y}{\partial k}=A(1-\alpha) k^{-\alpha} g^{a}=A(1-\alpha) \frac{g}{k}()^{a}
$$


Under the tax rate $\mathrm{T}$, the return on capital is now

$$
r=(1-\tau) \frac{\partial y}{\partial k}=A(1-\alpha) K^{-a} g^{a}=A(1-\alpha) 1(-\tau) \frac{g}{k}()^{a}
$$

With the presence of a flat-rate income tax at rate $\mathrm{T}$, this return is $(1-\mathrm{T}) *(\partial y / \partial k)$, where $\partial y / \partial k$ is given from equation (8).

Therefore, the growth rate of consumption is now

$$
\gamma=\frac{\Delta c}{c}=\frac{r-\rho}{\theta}=\frac{1}{\theta}\left[A(1-\alpha) 1(-\tau) \frac{g}{k}()^{\alpha}-\rho\right]
$$

Substituting equation (6) into equation (10) yields

$$
\gamma=\frac{\Delta c}{c}=\frac{r-\rho}{\theta}=\frac{1}{\theta}\left[A^{\frac{1}{(1-\alpha)}}(1-\alpha) 1(-\tau) \tau 0^{\frac{a}{(1-\alpha)}}-\rho\right]
$$

From equation (11), taxes on the influence of the growth rate is reflected in two aspects, 1-T representing macro tax burden on capital on behalf of after-tax marginal product negative effects, $\tau^{\frac{a}{(1 \cdot a)}}$ representing the government service to capital marginal product is effect after tax. If the economy no transformation dynamic, the government sets the capital $k$ and production $\mathrm{y}$ to grow at the same rate $\mathrm{T}$.

From equation (11), derivation of the growth rate $y$ on the tax rate $\mathrm{T}$, and according to the optimum conditions $\partial Y / \partial T=0$, draw a conclusion that $T^{*}=a$. In a word, when the economic growth rate reached the maximum, the optimal taxation $T^{*}$ is the output elasticity of the financial scale a.

The macro tax burden and economic steady growth rate is the relationship between the fall $U$. When $T<T^{*}$, macro tax burden on the capital marginal product is effect after more than negative effects, economic growth with $\mathrm{T}$ increase with the increase of the macro tax burden; When $\mathrm{T}=\mathrm{T}^{*}$, negative effects and macro tax burden is equal to effect, the economic growth rate reaches maximum; When $\mathrm{T} \mathrm{T}^{*}$, macro tax burden of its economic impact of negative utility more than is utility, make the steady-state growth rate and began with the increase of the macro tax burden, and continue to drop. So in terms of the influence of on macro economy, the optimal macro taxation value should be $\mathrm{T}^{*}$. 
Therefore, the optimal tax rate in calculation, this article uses the Cobb-Douglas production function expansion mode:

$$
\operatorname{Ln} Y=C+\alpha_{1} \ln G+\alpha_{2} \ln K+\gamma \ln L+\varepsilon
$$

Where $\mathrm{Y}$ is GDP, $\mathrm{K}$ is Gross Capital Formation, $\mathrm{G}$ is total government spending = budgetary expenditures + non-budgetary expenditures, and $L$ is the total amount of the labor force in the employment. The optimal tax rate is $r^{*}=a 1$.

Study on the optimal taxation of logistics industry, I will use industry data to replace the variables of Cobb-Douglas production function expansion mode. Use the logistics industry business income as $\mathrm{Y}$, because business income is the value of products and services that created by an industry; With the fixed assets and inventory of the logistics industry replace K, because the gross capital formation including the total fixed assets formation and inventory; Use the owner's equity of the logistics industry replaces $\mathrm{G}$ government spending, because it is equivalent to government spending to run an enterprise and must invest money, namely enterprise cost of investment-the owners' equity, so this paper used the owner's equity to replace government spending.

So in equation (12), $\mathrm{Y}$ is business income of the Logistics industry, $\mathrm{K}$ is the fixed assets and inventory of the logistics industry, $\mathrm{G}$ is the owner's equity of the Logistics industry, and $\mathrm{L}$ is the total amount of the labor force in the employment.

\section{The calculation of the optimal taxation of logistics industry}

As a new industry, the statistics of logistics industry is not perfect. In our existing government statistics, it does not have independent statistic index system of logistics. Transportation and Storage industry is the most basic and important part of modern logistics, this paper analyzed the statistical data of transportation and Storage industry. According to the collected statistical data, this paper analyzed the state-owned transportation and storage industry, and listed companies of transportation and storage industry. 


\subsection{Calculate the optimal taxation of the State-owned Transportation and Storage industry}

The calculation in this part used the state-owned enterprise of transportation and storage industry as the sample. Data mainly comes from 2002-2010 "Chinese fiscal yearbook", "China statistical yearbook ".

\subsubsection{Unit root stationary test}

Because of the existence of the time trend, the economical time series data usually is nonstationary, and used a non-stationary time series to regression another non-stationary time series can lead to a false return. To test whether the regression with meaning, it need time series variables stationary test, this paper used Eviews software to test the steadiness of the data. Test results as is shown in Table 1.

\begin{tabular}{|c|c|c|c|}
\hline variables & ADF test statistic & Critical value & $\begin{array}{c}\text { exist unit root or } \\
\text { not }\end{array}$ \\
\hline $\ln Y$ & 3.955 & -2.886 & Y \\
\hline InG & 3.238 & -2.886 & Y \\
\hline $\ln K$ & 5.911 & -2.886 & Y \\
\hline $\ln L$ & -2.357 & $-1.996 * *$ & $\mathrm{~N}$ \\
\hline $\mathrm{D}(\ln \mathrm{Y})$ & 0.556 & -2.937 & Y \\
\hline $\mathrm{D}(\ln \mathrm{G})$ & -0.950 & -2.937 & Y \\
\hline $\mathrm{D}(\ln \mathrm{K})$ & 0.114 & -2.937 & Y \\
\hline $\mathrm{DD}(\ln \mathrm{Y})$ & -1.728 & $-1.597^{*}$ & $\mathrm{~N}$ \\
\hline $\mathrm{DD}(\ln \mathrm{G})$ & -4.734 & $-3.206 * * *$ & $\mathrm{~N}$ \\
\hline $\mathrm{DD}(\ln K)$ & -3.075 & $-3.007 * * *$ & $\mathrm{~N}$ \\
\hline
\end{tabular}

$*$ represents $10 \%$ of the level of significance, $* *$ represents $5 \%$ of the level of significance, $* * *$ represents $1 \%$ of the level of significance

Table 1. ADF unit root test results

Table 1 shows that all of the variable value in statistical sense is located in the critical value, can't refuse to have a unit root and the original hypothesis that all variables is level is not stationary sequence. All one order difference variables are not located in the critical value, refused to have a unit root of the original hypothesis that is stationary series. Therefore, we can conclude that all of the above variables have a unit root, but one order or second-order difference variables have no unit root, meaning that these sequences or relatively stable sequence. Because the sequence contains sample size is small, so the sequence of secondorder difference no unit root the event that the sequence is stable. 


\subsubsection{Regression analysis}

Through the regression analysis of the statistical software SPSS, we get the maximum likelihood estimation of parameters, standard deviation, coefficient and t-statistics, as shown in Table 2.

\begin{tabular}{|c|r|r|r|}
\hline variables & coefficient & standard deviation & \multicolumn{1}{|c|}{ t-statistics } \\
\hline Constant & -14.293 & 4.394 & -3.253 \\
\hline InG & 0.040 & 0.248 & 0.162 \\
\hline InK & 1.543 & 0.308 & 5.016 \\
\hline InL & 1.610 & 0.512 & 3.146 \\
\hline
\end{tabular}

Table 2. Estimated coefficient of the state-owned transportation and storage industry

So, the regression equation is $\operatorname{Ln} Y=-14.293+0.0403 * \ln G+1.543 * \ln K+1.610 * \ln L$

(Adjust R2 $=0.988, F=221.035)$

Regression showed that, the adjusted $\mathrm{R}$ square of the equation is 0.988 , namely the adjusted $\mathrm{R}$ square is more is better; model can be a good explanation of the relationship between the variables, and through the level of significance test. InK is in $1 \%$ of the level of significance, InG and InL are in $5 \%$ of the level of significance. Such as equation showed, a1 is 0.040 . The optimal taxation of the state-owned transportation and storage industry is $4.0 \%$.

According to our calculations, from year 2001 to 2009, the actual tax burden of the stateowned transportation and storage industry were $4.23 \%, 4.29 \%, 4.54 \%, 4.49 \%, 4.18 \%$, $4.91 \%, 5.89 \%, 5.22 \%, 4.96 \%$. They were all greater than the optimal taxation.

\subsection{Calculate the optimal taxation of Listed Companies in Transportation and Storage industry}

This part calculated and analyzed the 79 listed companies of the transportation of storage industry that selected in Shanghai stock exchange and Shenzhen stock exchange. Rule out the listed companies that were ST and *ST, 59 listed companies of the transportation of storage industry were selected. The financial data is mainly from CSMAR database, and the related report data sited on Shanghai stock exchange and Shenzhen stock exchange.

Through the regression analysis of the statistical software SPSS, we get the maximum likelihood estimation of parameters, standard deviation, coefficient and t-statistics, as shown in Table 3. 


\begin{tabular}{|c|r|r|r|}
\hline variables & coefficient & standard deviation & \multicolumn{1}{|c|}{ t-statistics } \\
\hline Constant & 13.953 & 0.588 & 24.985 \\
\hline InG & 0.036 & 0.010 & 3.744 \\
\hline $\operatorname{lnK}$ & 0.066 & 0.013 & 5.110 \\
\hline $\operatorname{lnL}$ & 0.729 & 0.065 & 11.097 \\
\hline
\end{tabular}

Table 3. Estimated coefficient of listed companies in transportation and storage industry

So, the regression equation is $\ln Y=13.953+0.036 * \ln G+0.066 * \ln K+0.724 * \ln L$

(Adjust R2 $=0.721, \mathrm{~F}=92.946$ )

Regression showed that, the adjusted $\mathrm{R}$ square of the equation is 0.721 ; model can be a good explanation of the relationship between the variables, and through the level of significance test. InK, InG and $\mathrm{InL}$ are in $1 \%$ of the level of significance. Such as equation showed, a1 is 0.036 . The optimal taxation of listed companies in transportation and storage industry is $3.6 \%$.

According to our calculations, the actual tax burden of listed companies in transportation and storage industry was above $5 \%$, the mean is $6.99 \%$. There are 116 sample data more than the optimal tax, accounting for more than $67 \%$ of the total sample.

The calculations show that, the actual tax burden of listed companies in transportation and storage industry is greater than the optimal taxation.

\section{Conclusions and Policy Proposes}

\subsection{Conclusions}

Based on the theoretical analysis, I put forward the model used in this paper--Cobb-Douglas production function extension mode. The empirical analysis on the state-owned companies and the listed companies of transportation and storage industry, and come to conclusions that,

- The optimal taxation of the state-owned transportation and storage industry is $4.0 \%$, lower than the average lever of the actual tax burden from 2001-2009.

- The optimal taxation of the listed companies of transportation and storage industry is $3.6 \%$, lower than the average lever of the actual tax burden.

Affected by lack of Chinese logistics industry statistics, we only estimate the optimal taxation of state-owned logistics enterprises and listed companies of logistics. But, the two samples are the main force of the logistics industry in China, and the optimal tax calculation result is close, so we can believe that the calculation results are representative. 
The results show that, the actual tax burden of China's logistics industry is higher than the optimal taxation. This implies that tax problem has restricted the normal operation of the logistics industry in China. Because of the relationship between tax and economic, tax burden achieves the optimal level, it will play the largest role in promoting the economy. Our country should take measures to reduce the tax burden of logistics industry, in order to promote the development of the logistics industry. In March 2009, the state council issued "The logistics industry restructuring and revitalization plan" in August 2011, the general office of the state council issued "about promoting the healthy development of the logistics industry policy measures"; the suggestions are clear requirements about "earnestly alleviate the logistics enterprise tax burden". The Government should implement practically the measure to reduce the tax burden of the logistics industry as soon as possible.

\subsection{Putting forward policy proposes}

The standing committee of state council decided that, from January 1, 2012, business tax change VAT pilot in transportation industry and modern service industry in Shanghai. Bringing the logistics industry into the pilot scope, reflected the orientation of the country industrial policy, helped to solve repeat tax problems, and support the development of modern logistics industry. During the period of the tax policy reform, we should reduce the tax burden of the logistics industry and improve logistics industry related tax policy.

\subsubsection{The tax rate in every link of logistics business is not uniform}

Under the current tax system in China, tax items of logistics business are divided into transport and services. One tax rate is $3 \%$, including transportation, loading and unloading, handling, carrying; another tax rate is $5 \%$, including warehousing, distribution, agency etc. In every link of logistics business, the tax items are not uniform, tax rates are not the same, the invoice are various. It is the bottleneck of the development of the logistics industry policy for many years. For this, the general office of the state council "the opinion about promoting the healthy development of the logistics industry policy measures" explicitly pointed out that, "combination with the VAT reform, and as soon as possible to solve the problems that business tax rates are not unified." Business tax change VAT pilot still set the logistics industry into two classes of taxable services. They are "transportation service" and "logistics support service", transportation service according to the VAT rate of $11 \%$, logistics support services according to the VAT rate of $6 \%$.

Integration of various types of logistics resources, implementing the supply chain management, integrated operation, carrying out a vote on business, one-stop service, it is the 
basic operational mode of logistics industry, is also a customer's common service requirements. In the practical operation, every logistics business is linked, it is difficult to distinguish between transportation service and logistics support service, and divided artificially does not meet the need of modern logistics operation, has also increased the difficulty of tax collection and administration work.

We suggest that, under no change basic framework of "the pilot plan ", remove "goods transport services" from "transportation service", put it into the" logistics auxiliary service ", use the tax rate of $6 \%$ by the state council spirit, unify the tax rate in each link of logistics business, support the integration of logistics operation, also can solve the problems that brought by the goods transportation business tax increase of the pilot, and is consistent with the purpose of the pilot.

\subsubsection{Business tax change VAT aggravates the tax burden of transportation business}

Some transportation enterprises participate in a pilot of Business tax change VAT, and appeared raising the tax burden. The main reason of Preliminary analysis is that, as capital organic composition different enterprise invests different, input tax and the output tax doesn't match in a certain period. Transportation enterprise's main capital investment is vehicles, if put it into the pilot reform, most vehicles of transportation enterprise are purchased before January 2012, deductible VAT is small in the early period, sales VAT is relatively large. At the same time, because reform is not complete, it affects the transportation enterprise deduction VAT to fully deduct. For example, toll fee expenditure is one of the main management costs of transportation enterprise, according to recently released report of the China federation of logistics \&purchasing, it shows that the road toll account transportation cost for $34 \%$ on average. Because the bridge charge is not included in the pilot range of business tax change VAT, toll fee happens in transportation enterprise can't be deducted and increases the tax burden. For example, refueling vehicles fee spending happens in some transportation enterprises is not convenient to obtain special VAT invoices or not in time, also bring the input tax deduction the contradiction.

We suggest that, firstly, reducing VAT rate of transportation business. Second, it is to appropriately increase deductible items of the input VAT. For the large proportion of logistics enterprise cost, such as the toll fee, insurance premium, housing rents, take into the range of input VAT deduction. For some relatively fixed and the spending that is hard to obtain the special VAT invoices (such as fuel consumption, the repairs, etc.), according to the average of the industry, estimates the proportion of deduction, the spending of the project is taken as a minus income, and calculates the output tax. So, it can not only take care of all the logistics industry, nationwide operation that is not easy to get the special VAT invoices, also can reduce the difficulty of the tax supervision. 
At present the tax burden level of logistics industry is on the high side, against the development of logistics industry, it is contrary to the original intent of vigorously developing the logistics industry. We should take the optimal taxation of logistics industry as a standard of tax burden, make its tax burden to achieve the optimal level, so as to play the important role in promoting the economic development, and promote the development of the logistics industry.

\section{References}

Barro, R.J. (1990). Government Spending in a Simple Model of Endogenous Growth. Journal of Political Economy, 98(5), 103-125. http://dx.doi.org/10.1086/261726

Dongmei, W., \& Cairong, Z. (2011). Research on Tax Burden of Transportation and Storage Industry in China. SciTe Press, 4, ICEIS2011. Beijing, China, 586-590.

Dongmei, W., \& Songdong, J. (2009). Research on Taxation Burden of Logistics Industry in China. Circulation Economic of China, 1, 25-28.

Ramsey, F.P. (1928). A Mathematical Theory of Saving. The Economic Journal, 38(152), 543559. http://dx.doi.org/10.2307/2224098

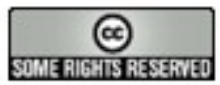

Article's contents are provided on a Attribution-Non Commercial 3.0 Creative commons license. Readers are allowed to copy, distribute and communicate article's contents, provided the author's and Journal of Industrial Engineering and Management's names are included. It must not be used for commercial purposes. To see the complete license contents, please visit http://creativecommons.org/licenses/by-nc/3.0/. 